\title{
Die another day: Duration in German import trade
}

\section{Journal Article}

\section{Author(s):}

Nitsch, Volker

Publication date:

2009

Permanent link:

https://doi.org/10.3929/ethz-b-000157250

\section{Rights / license:}

In Copyright - Non-Commercial Use Permitted

\section{Originally published in:}

Review of world economics 145(1), https://doi.org/10.1007/s10290-009-0008-3 


\title{
Die another day: duration in German import trade
}

\author{
Volker Nitsch
}

Published online: 13 March 2009

(C) Kiel Institute 2009

\begin{abstract}
International trade patterns at the product level are surprisingly dynamic. The majority of trade relationships exist for just a few, often only one to three, years. In this paper, I examine empirically the duration in German import trade at the 8-digit product level from 1995 to 2005. I find that survival probabilities are affected by exporter characteristics, product type and market structure. Specifically, I show that the duration of exporting a product to Germany is longer for products obtained from countries that are economically large and geographically close to Germany; for products with large trade value and a low elasticity of substitution; and for trade pairs that command a large share of the German import market and are characterized by two-way trade.
\end{abstract}

Keywords Survival $\cdot$ Product $\cdot$ Relationship $\cdot$ Pattern

JEL Classification $\mathrm{F} 14 \cdot \mathrm{F} 19 \cdot \mathrm{C} 14 \cdot \mathrm{C} 41$

\section{Introduction}

In 2004, Germany reported positive imports in 9,756 product categories, according to the most detailed (8-digit) product level classification in European trade statistics. The products were obtained from virtually all over the world, with official statistics listing 236 supplying countries and territories. Since most products were imported from more than one supplier, there were, in total, 206,727 product-country pairs (or

\footnotetext{
V. Nitsch $(\bowtie)$

KOF Swiss Economic Institute, ETH Zurich,

Weinbergstrasse 35, 8092 Zurich, Switzerland

e-mail: nitsch@kof.ethz.ch

V. Nitsch

Department of Economics, Free University Berlin, Berlin, Germany
} 
"varieties"). Interestingly, this number has been relatively stable over time; for other years, numbers of similar magnitude are observed. For instance, there were 202,604 trade pairs in 2003 (with imports of 9,976 products from 236 countries) and 200,706 trade pairs in 2005 (with imports of 9,697 products from 239 countries). In combination with other evidence on the (short-run) persistence in international trade (e.g., the empirical success of the gravity model of trade, the role of networks in trade), the small variation in the total number of product-level trade relationships may be just another indication that trade patterns are relatively stable over time. ${ }^{1}$

Contrary to this belief, however, Besedeš and Prusa (2006a, b) have recently argued in a series of papers that trade relationships are often very short-lived. Examining the duration of U.S. imports, they find that the U.S. pattern of foreign sourcing is surprisingly dynamic; the median duration of importing a product from a foreign supplier in their sample is just 1 year. As a result, the stability of aggregate trade patterns may mask considerable turnover at the product level, with a large fraction of suppliers entering and exiting the market each year.

Data for German import trade generally confirm Besedeš and Prusa's (2006a) findings. Of the 206,727 product-country pairs in 2004, 49,621 pairs (about 24\%) were non-existent a year earlier, while 49,928 pairs (about 24\%) died in the following year; a subset of 27,824 pair-wise trade relationships (about 13\%) was observed in 2004 (i.e., in 1 year) only. However, there is also considerable heterogeneity across products and countries. Most notably, some products were repeatedly imported from a particular country over a relatively long period of time; about one-tenth of all trade relationships in 2004 have been in existence for at least a decade.

This paper examines the duration of trade relationships in more detail. In particular, I aim to identify relationship-specific characteristics that help to explain the observed differences in the duration of trade. Besedeš and Prusa (2006b) find, based on a matching model, that survival rates are higher for differentiated products than for homogeneous products; they also show that duration increases with initial trade size. In this paper, I take a much broader view. In particular, I ask: Do country characteristics, such as proximity or common language, matter for survival? Are there any product characteristics, such as product sophistication, that affect the duration of trade? And to what extent do market characteristics play a role, such as market entry of a foreign competitor?

To analyze these questions, I examine a new data set of German import trade from 1995 to 2005 . The data set comprises trade values and quantities at the 8-digit Combined Nomenclature $(\mathrm{CN})$ level which is the most detailed product classification to designate goods and merchandise in European Union (EU) trade statistics; the $\mathrm{CN}-8$ level contains about 13,000 product codes. Based on this data, I use various techniques, including a Cox hazard model, to explore the survival time of importing a product from a particular country.

\footnotetext{
1 The gravity model of trade is highly successful in explaining bilateral trade flows between two countries with their economic mass and the distance between them-measures that change (at best) only slowly over time. The network view of trade emphasizes that search for a trading partner is costly and therefore may be completed at some point in time (even before the best match is achieved).
} 
I find that the duration of a trade relationship is indeed strongly and significantly associated with characteristics of the supplier country, specific features of the imported product, as well as the structure of the (import) market. Specifically, I find that country pair-specific features that are typically identified to increase bilateral trade in gravity models are also beneficial for the duration of trade. Further, trade relationships tend to last longer for differentiated products and for products with a low elasticity of substitution. Finally, large transaction values as well as German exports of a particular product (i.e., two-way trade) increase the probability of survival.

The remainder of the paper is organized as follows. Section 2 briefly reviews the relevant literature. Section 3 describes the data. Section 4 is the main part of the paper, presenting the empirical results. Section 5 provides a short conclusion.

\section{Literature}

In standard models of international trade, the duration of trade is typically ignored. Some models appear to imply that trade patterns are highly static and persistent. In these models, a trade relationship, once established, will almost last forever. For instance, according to the factor proportions theory, trade is based on differences in (relative) factor endowments. To the extent that such differences remain in place (as they often do between countries over time), a trade relationship remains undissolved.

Other models focus (more explicitly) on the dynamics of trade, but rarely discuss exits from export markets. These models typically cover trade dynamics by considering market entry of new exporters. The implications (of this growing trade diversity) for existing exporters, however, are often less clear; initial trade patterns may be reinforced or reversed, depending on circumstances. ${ }^{2}$ Still, it is interesting to note that also in these models patterns of specialization change at best only gradually. Shifts in the pattern of specialization may be associated with, for instance, the life cycle of a product, the diffusion of technology or differences in factor accumulation; see, for instance, Vernon (1966), Grossman and Helpman (1991). None of these reasons, however, helps explain the very short episodes (that are observed in the data) when a product is exported for just a few years.

It is even more striking that (the few) models that explicitly consider the duration of trade especially emphasize the stability of international trade patterns. Examples include models of hysteresis in trade, such as Baldwin and Krugman (1989). In these models, based on the existence of sunk market-entry costs, firms tend to serve an export market over relatively long periods of time. For instance, an exchange rate overvaluation may lead to (additional) entry by foreign firms which then do not exit

\footnotetext{
${ }^{2}$ Evenett and Venables (2002) find, for a sample of 23 developing countries, that the number of zeros in bilateral trade matrices has fallen considerably over time; their estimates imply that the increase in the number of trading partners (what they call "geographic spread of trade") accounts for about one-third of developing economies' export growth since 1970. Kehoe and Ruhl (2003) argue along similar lines; they study six episodes of major trade liberalization and find that the decrease in trade barriers has mainly benefited trade in goods that were not traded before. For a contrasting view, see Helpman et al. (2008).
} 
after the exchange rate shock has passed. In similar fashion, search-cost models of trade view the connection between buyers and sellers as a search process that, because of its costliness, is terminated at some "reservation match"; that is, at some point in time, firms stop searching for alternative partners even if they have not yet found the perfect partner. As Rauch (2001, p. 1179) emphasizes, networks help to reduce such partner-related search costs because network members have thorough knowledge of each others' characteristics and, more importantly, "their members are engaged in repeated exchange that helps sustain cooperation/collusion". To further illustrate this point, Rauch (2001, p. 1179) quotes Egan and Mody (1992) who state that "Most U.S. buyers interviewed for this study preferred long-term, stable and direct relationships with both developed and developing country suppliers".

Empirical studies on trade dynamics have mainly focused on changes in the pattern and composition of international trade. Feenstra and Rose (2000), for instance, examine the ordering when countries begin to export a particular product to the United States. Redding (2002) documents the evolution in the pattern of specialization across OECD countries. While these studies often emphasize the mobility in trade patterns, the duration of trade has previously been analyzed only by Besedeš and Prusa (2006a, b) and Besedeš (2008). There is also a recent related literature that studies the duration of prices. Gopinath and Rigobon (2008), for instance, examine the stickiness of U.S. import prices.

\section{Data}

Any estimate of the duration of trade is highly sensitive to the analyzed level of product classification. Periods of continued trade tend to become longer for more aggregate industries because the wider the range of products that is covered by an industry classification, the higher is the probability that at least one product of this category is traded in a given year. At a very detailed level of product description, in contrast, even a minor change of product specifications may lead to a reclassification of an otherwise identical product, thereby resulting in a recorded failure of a trade relationship. Also, (regular) modifications of product codes may affect the results for individual products more strongly than for broad product groups or industries.

In this paper, I make use of a new and previously unexplored data set of productlevel trade for Germany. Trade values and quantities are reported at the 8-digit $\mathrm{CN}$ level, which is the most detailed product classification in European Union trade statistics. The data are provided by Eurostat and are available online at http://ec.europa.eu/eurostat.

According to the European Commission (EC), the $\mathrm{CN}$ is comprised of the (widely used and often better known) Harmonized System (HS) nomenclature, which is run by the World Customs Organization, with further Community subdivisions. With about 13,000 product codes, however, the $\mathrm{CN}-8$ classification covers a smaller number of products than the 10-digit HS scheme which is used to classify U.S. trade. To illustrate the level of product detail, Table 1 lists the five product codes with the smallest and largest import values for Germany in 2004. As shown, there is enormous variation in the importance of individual products. The smallest import value that is 
Table 1 German imports at the product level by import value, 2004

\begin{tabular}{|c|c|c|}
\hline Product code & Product description & Import value (euro) \\
\hline 27090090 & $\begin{array}{l}\text { Petroleum oils and oils obtained from bituminous minerals, } \\
\text { crude (excl. natural gas condensates) }\end{array}$ & $24,991,366,847$ \\
\hline 27112100 & Natural gas, gaseous & $13,134,110,032$ \\
\hline 87032319 & $\begin{array}{l}\text { Motor cars/station wagons/racing cars for transport of } \\
\text { persons, otto cycle, cylinder capacity }>1.500-3.000 \mathrm{CC} \text {, } \\
\text { new (excl. caravans/for } \geq 10 \text { persons) }\end{array}$ & $9,599,081,747$ \\
\hline 88024010 & $\begin{array}{l}\text { Aeroplanes and other powered aircraft of an unladen weight } \\
>15.000 \mathrm{~kg} \text {, for civil use (excl. helicopters and dirigibles) }\end{array}$ & $8,822,268,329$ \\
\hline \multirow[t]{3}{*}{87033219} & $\begin{array}{l}\text { Motor cars/station wagons/racing cars for transport of } \\
\text { persons, diesel/semi-diesel, capacity }>1.500-2.500 \mathrm{CC} \text {, } \\
\text { new (excl. caravans/for } \geq 10 \text { persons) }\end{array}$ & $8,352,035,423$ \\
\hline & Mean & $58,979,216$ \\
\hline & Median & $7,518,391$ \\
\hline 43018030 & $\begin{array}{l}\text { Raw furskins of marmots, whole, with or without heads, } \\
\text { tails or paws }\end{array}$ & 511 \\
\hline 29251930 & $\begin{array}{l}N, N^{\prime} \text {-Ethylenebis " } 4,5 \text {-dibromohexahydro-3,6- } \\
\text { methanophthalimide" }\end{array}$ & 509 \\
\hline 29242400 & Ethinamate (inn) & 508 \\
\hline 02109959 & $\begin{array}{l}\text { Edible offal of bovine animals, salted, in brine, } \\
\text { dried or smoked (excl. thick skirt and thin skirt) }\end{array}$ & 503 \\
\hline 01019030 & Live asses & 500 \\
\hline
\end{tabular}

Total number of products with positive imports is 9,756

recorded in this year is 500 euro, which is actually below the smallest statistical threshold level for reporting trade (to reduce the burden from statistical formalities on businesses). ${ }^{3}$ The product categories with the largest import values are, as expected, natural resources, passenger cars, and airplanes.

The trade data are available for the 11-year period from 1995 to 2005 . For each year, I observe, at the product level, the value of German imports from a given country. That is, the total number of trade observations for all possible combinations of products, countries and years is about 33 million (about 13,000 products $\times 235$ countries $\times 11$ years). However, most of these potential trade relationships are nonexistent; the number of observations with positive trade is about 2.2 million (about $6 \%$ of the sample). Moreover, the majority of these non-zero trade observations are small in value. About $30 \%$ of Germany's imports by product-country pair have a value of less than 10,000 euro; about $60 \%$ have a value of less than 100,000 euro. Figure 1 provides a histogram of trade observations by size groups of factor $10 .{ }^{4}$

\footnotetext{
3 Eurostat notes a transaction threshold of 1,000 euro or $1,000 \mathrm{~kg}$ in extra-EU trade statistics; see http://europa.eu.int/estatref/info/sdds/en/text/ext_sm.htm. The OECD reports thresholds for intra-EU trade ranging from 30,000 euro to as much as over 600,000 euro while the recommended threshold for extra-EU trade is 800 euro; see http://www.oecd.org/dataoecd/55/11/2539563.pdf.

${ }^{4}$ Given the statistical thresholds for reporting transactions, the share of small-value trade observations can be expected to be even larger. Still, the minimum reported trade value in the sample is 69 euro (for imports under CN code 04MMM000 from Malta in 2005).
} 


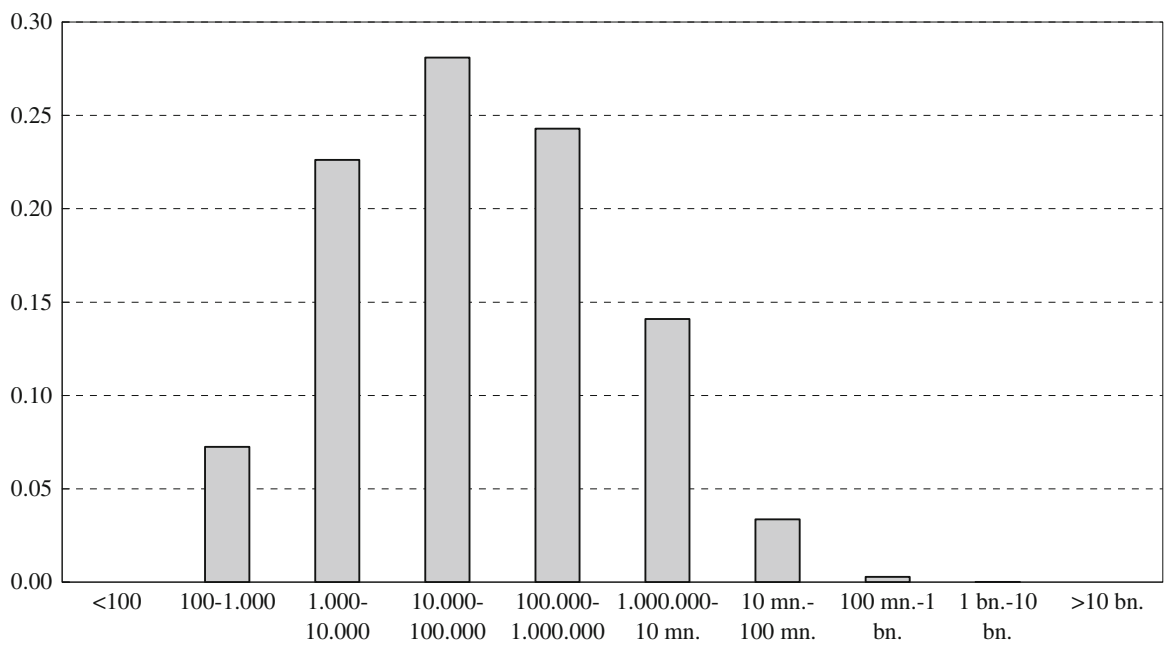

Fig. 1 Histogram of German import values by product-country pair

Based on this data, I compute some additional statistics that help to characterize a pair-wise trade relationship. For instance, as noted before, it is possible to observe the total size of the German import market for a given product specification (see Table 1); dividing then pair-wise shipments by Germany's total imports of a product gives a country's market share in supplying this product to Germany. Similarly, the number of countries from which Germany has imported a product in a given year is easily identified. Table 2 a indicates that Germany typically obtains a product from various sources. The median number of suppliers is 17 ; less than $5 \%$ of the products are imported from just one (unique) supplying country. ${ }^{5}$ Also, the degree of geographic concentration in the German import market is observed. Summing the number of products (with positive imports) by country gives an indication of product diversity in a country-pair relationship. As shown in Table 2b, distance to the German market appears to be an important determinant of product diversity in the bilateral trade relationship; this observation confirms recent findings by Baldwin and Harrigan (2007) on the incidence of non-zero trade in U.S. productlevel trade statistics.

For each product and country, I also compute the Herfindahl index as a measure of trade concentration. The Herfindahl index is the sum of the squared shares of individual product-country pair import values in Germany's total imports either for a specific product or from a particular country. ${ }^{6}$ That is, the higher the value of the Herfindahl index, the less diversified geographically are Germany's imports of a particular product (for products) and the more specialized is a country in shipping a

\footnotetext{
5 This result does not necessarily contradict the finding in Haveman and Hummels (2004) that importers buy from very few of available exporters.

${ }^{6}$ Specifically, the Herfindahl index is defined for products as $H_{t}^{p}=\sum_{c}\left(x_{c t}^{p} / X_{t}^{p}\right)^{2}, c=1, \ldots, C$, and for countries as $H_{t}^{c}=\sum_{p}\left(x_{c t}^{p} / X_{c t}\right)^{2}, p=1, \ldots, P$, where $x_{c t}^{p}$ denotes German imports of product $p$ from country $c$ in year $t$, and $X^{p}$ and $X_{c}$ denote total German imports of $p$ and from $c$, respectively.
} 
Table 2 Product structure of German imports, 2004

Number of countries

(a) Number of countries from which a product is imported

$\begin{array}{ll}\text { Maximum } & 115 \\ \text { Mean } & 21.19 \\ \text { Median } & 17 \\ \text { Minimum (308 products) } & 1\end{array}$

Exporter

Number of products

(b) Number of products imported from a country

$\begin{array}{ll}\text { Netherlands } & 8,008 \\ \text { France } & 7,830 \\ \text { Italy } & 7,364 \\ \text { Switzerland } & 7,013 \\ \text { Belgium } & 6,911 \\ \text { Mean } & 875.96 \\ \text { Median } & 88 \\ \text { Four countries } & 1\end{array}$

particular product to Germany (for countries). Table $3 \mathrm{a}$ and $\mathrm{b}$ list the upper and lower bounds of the index as well as the median and mean values. ${ }^{7}$ Ranking indices by products, selected sorts of specialty food (which is actually defined by the region of origin) are imported almost exclusively from one supplying nation, while imports of various textile products are the least concentrated on a particular source country; a more detailed description of the results is provided in the working paper version of this paper (Nitsch 2007). In similar fashion, shipments to Germany from (economically) small countries are often dominated by a single commodity, while large and/or nearby countries tend to deliver a highly diversified range of products.

In addition, it is possible to derive from this data, similar to Besedeš and Prusa (2006a), the length of time that a country has continuously shipped a product to Germany. Focusing on the frequency of changes in the German import structure, this approach essentially ignores the actual size of imports, but goes beyond the simple zero-one question of when a country is on or off the German import market. Figure 2 graphically illustrates the procedures to construct the relevant variables for an exemplary product category, peanut butter (CN code 20081110). As shown, Germany has imported peanut butter from a total of 25 countries over the sample period from 1995 to 2005. However, not all of these countries have shipped the product to Germany in each and every year. Circles denote years of an active trade relationship (with positive German import values of peanut butter from a particular country). Lines then mark episodes of a country continuously servicing the German market; these episodes are commonly referred to as "spells" so that the maximum

\footnotetext{
7 Only products imported from at least four suppliers and only countries shipping at least four products are reported. The results refer to 2004; aggregate figures for other years are identical.
} 
Table 3 Concentration in the German import market, 2004

Herfindahl index

(a) Supplier concentration by product (excl. products imported from less than four countries)

$\begin{array}{ll}\text { Maximum } & 1.000 \\ \text { Mean } & 0.369 \\ \text { Median } & 0.295 \\ \text { Minimum } & 0.049\end{array}$

Exporter

Herfindahl index

(b) Product specialization by exporter (excl. countries from which Germany imported less than four products)

Antigua \& Barbuda 0.995

Bermuda 0.993

Kiribati 0.990

Marshall Islands $\quad 0.985$

Liberia $\quad 0.983$

Mean 0.339

Median $\quad 0.228$

India $\quad 0.007$

Czech Republic $\quad 0.006$

Netherlands $\quad 0.006$

Italy $\quad 0.006$

$\begin{array}{ll}\text { Switzerland } & 0.003\end{array}$

length of a spell in my sample is 11 years. An event when a country stops exporting to Germany is labeled as "failure"; spells that fail during the sample period are shown in bold. At the extreme, a country exports a product to Germany every other year so that there are, for a given product-country pair, a maximum number of six spells and five failures in my sample.

Calculating duration then appears to be straightforward: it is simply the time (measured in years) that a trade relationship has been in existence (without interruption). Alternatively, applying statistical techniques from survival analysis, duration can be modeled as a sequence of conditional probabilities that a trade relationship continues after $t$ periods given that it has already survived for $t$ periods. ${ }^{8}$ Specifically, let $T$ be a random variable that denotes the length of a spell. Then, in discrete time, the survivor function is defined as

$$
S(t)=\operatorname{Pr}(T \geq t) .
$$

In similar fashion, the hazard function is the probability that the trade relationship dies after $t$ periods given that it has survived up to that point; that is,

$$
\lambda(t)=\operatorname{Pr}(T=t \mid T \geq t) .
$$

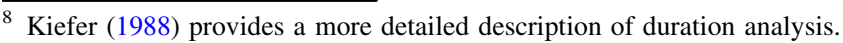




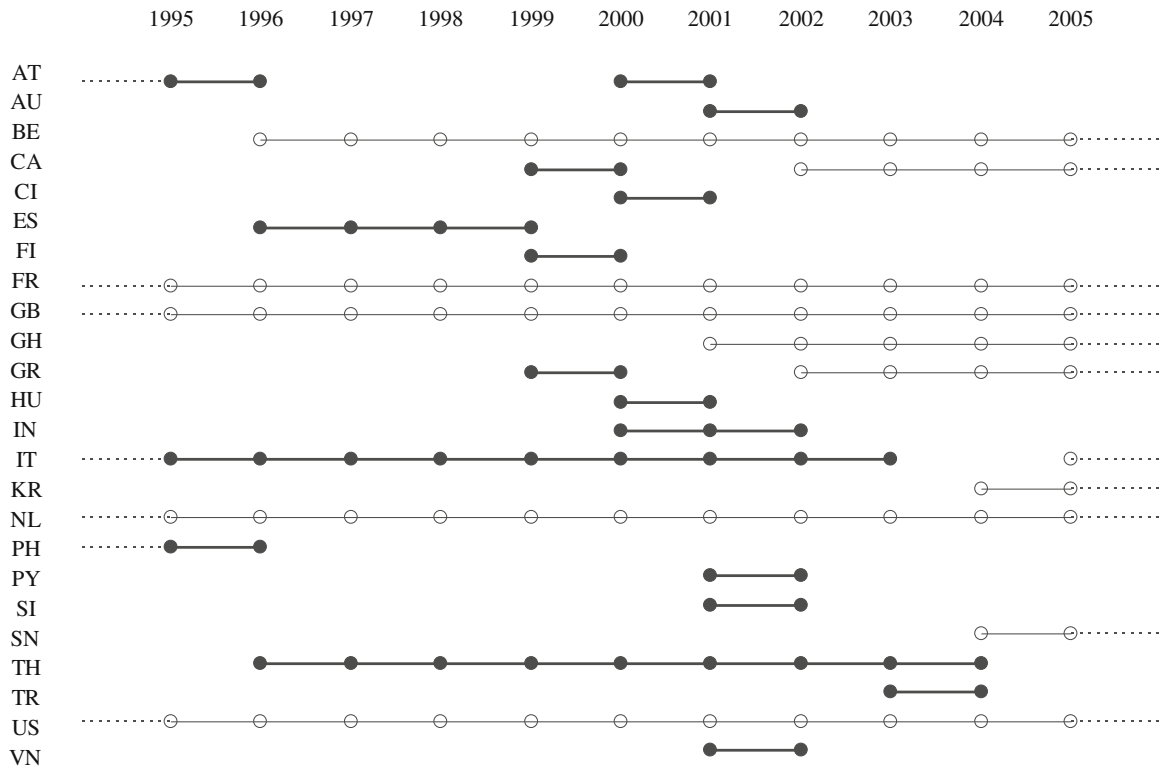

Fig. 2 Description of trade spells. Product code: 20081110 (Peanut butter). Note: Circles mark a year of positive imports from a particular country; lines indicate spells of consecutive years of positive imports. Full circles (and thick lines) denote completed spells (i.e., spells that died during sample period)

In practice, the survivor and hazard functions are estimated (in a non-parametric way) by computing the number of spells that survive (end) as a fraction of the total number of spells that are at risk after $t$ periods. ${ }^{9}$

An important issue for the analysis of duration data is censoring. Spells may begin before or end after the period under observation so that the observed spell length is shorter than the true length of the spell. For illustration, consider a trade relationship that is dissolved in 1995, the first year in my sample. Such a trade relationship is effectively observed as a (short) 1-year spell, although it might have been in existence for decades. Another type of censoring is introduced by the frequent revision of product descriptions. In each year, some product definitions are modified, often accompanied by the introduction of new product codes and the deletion of other product codes, so that a product may be reclassified from one code to another. As a result, for a reclassified product, the observed duration of a trade

\footnotetext{
9 More specifically, the Kaplan-Meier estimator of the hazard function is the fraction of spells that fail after $t$ periods of all spells that have survived $t$ periods. If the fraction of failures gets smaller for longer periods of time, trade relationships become more likely to be continued the longer they have been in existence, and the hazard function is downward sloping. Correspondingly, the estimator of the survivor function is the share of spells that survives at time $t$, but this time cumulative about all preceding time intervals. That is, if all spells survive and the ratio is one, the survivor function is flat at this interval; otherwise the function is stepwise declining.

Formally, $\hat{\lambda}(t)=d_{t} / N_{t}$ and $\hat{S}(t)=\prod_{t_{(i)} \leq t}\left(n_{i}-d_{i}\right) / n_{i}$, where $d_{t}$ denotes the number of spells that die after $t$ periods and $N_{t}$ is the total number of spells that have survived up to that point.
} 
(a)

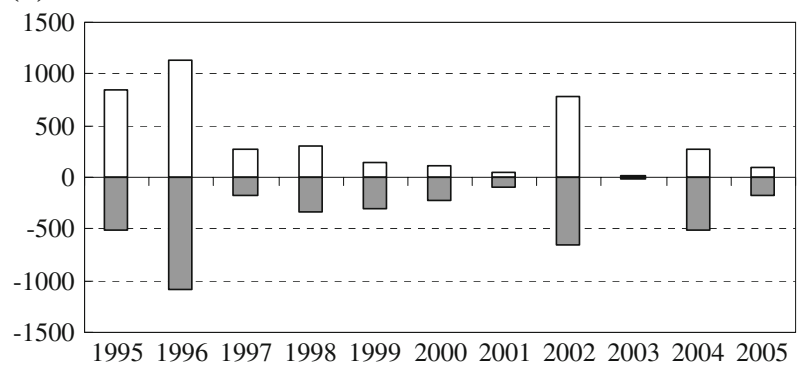

(b)

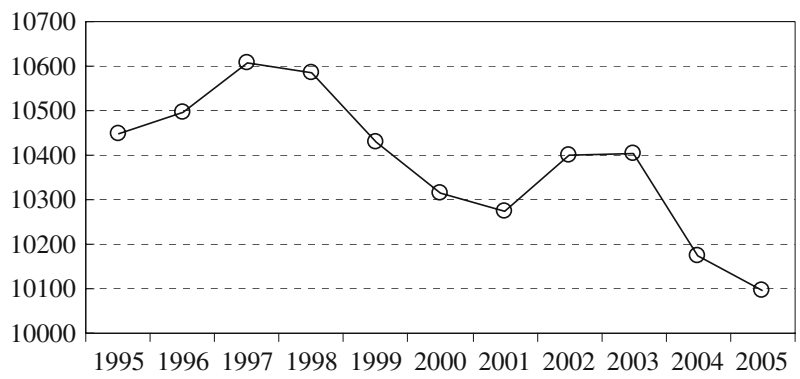

Fig. 3 Product codes at the CN-8 level. a Entries and exits. b Total number of codes

relationship is shorter than the true length of the partnership. Although Eurostat allows, in principle, to track changes in product codes, it is not possible to identify, based on this data, a continuous, uninterrupted trade relationship. ${ }^{10}$ Therefore, using a conservative approach to correct for reclassifications, I classify spells that begin when a new product code is created or that end when an existing product code is deleted as being censored.

Changes in product classification affect about $10 \%$ of the sample. As shown in Fig. 3a, about 500 new products are added to the statistics each year, while about the same number of product codes becomes obsolete, with large differences across years. Overall, the number of deleted product codes marginally exceeds the number of newly created codes so that the total number of product codes at the 8-digit CN level slightly decreases over time from about 10,500 in 1995 to about 10,000 codes at the end of the sample period (Fig. 3b).

Table 4 describes the data on German import trade in more detail. Uncorrected for censoring, the data set consists of 465,922 product-country pairs for which at least 1 year of (non-zero) exports to Germany is reported over the sample period from 1995 to 2005 . For the majority of these bilateral pairs, trade takes place over a single span of consecutive years ("spells"); the median number of spells per pair is one. However, some trade relationships were also dissolved and later re-established during the sample period so that the total number of spells in the sample amounts to

\footnotetext{
${ }^{10}$ For a description of changes in product codes, see Eurostat's Update of CN codes (available online at http://ec.europa.eu/eurostat/ramon/documents/cn_2008/formats_download/cn08upd_pdf.zip).
} 


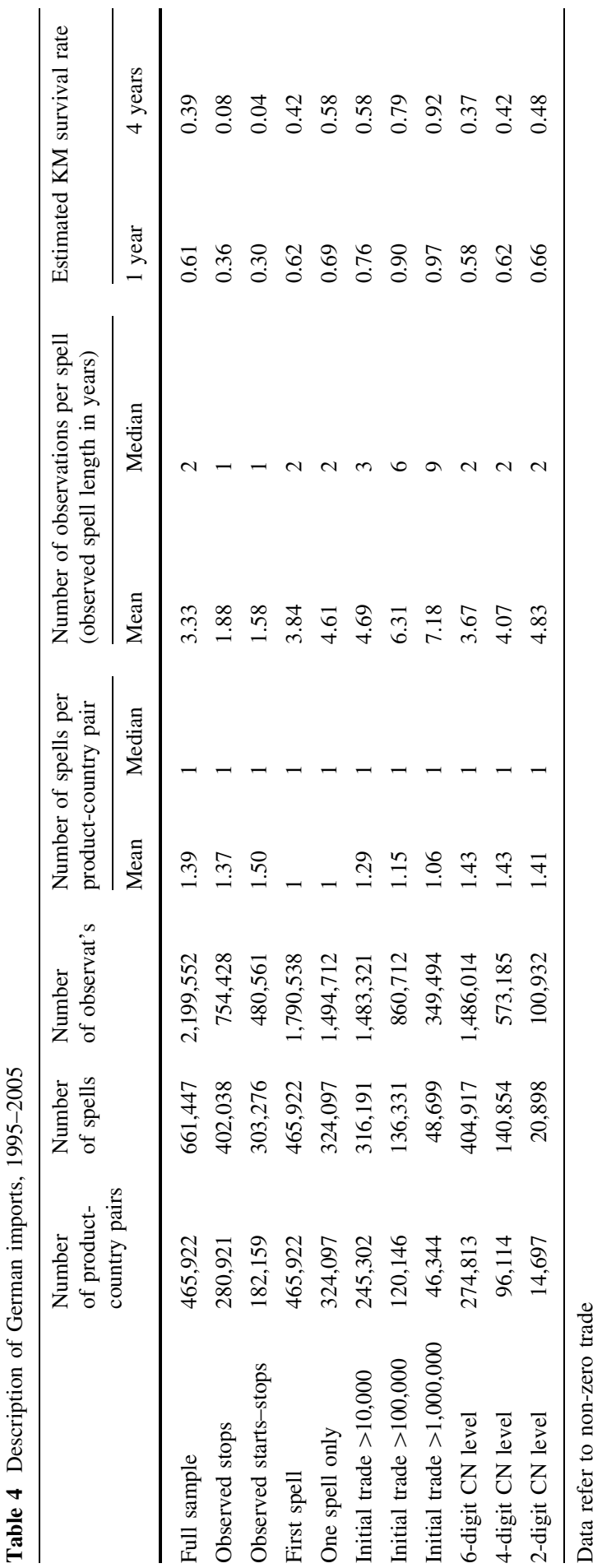




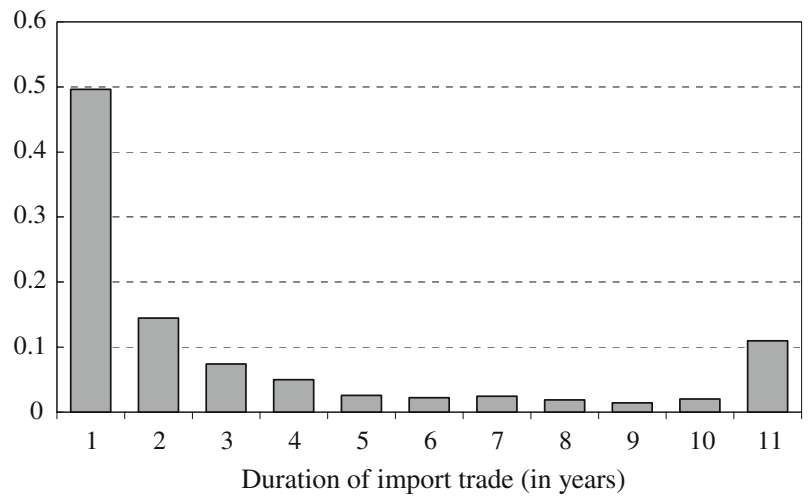

Fig. 4 Histogram of trade durations

661,447. These episodes of uninterrupted trade are the primary unit of analysis. Their maximum length in the full sample is 11 years when (non-zero) trade is recorded in every year from 1995 to 2005 . In practice, however, the average trade relationship lasts only about 3 years; the median duration is 2 years. That is, the vast majority of the trade relationships in German import trade appear to be very shortlived, confirming similar findings for the United States by Besedeš and Prusa (2006a).

Figure 4 provides a histogram for the observed duration of German imports. The figure illustrates the rapidly decreasing frequency of trade spells for longer periods; that is, most German import trade is highly dynamic. Still, a sizable share of about $10 \%$ of the spells survives the full sample period of 11 years and thus is remarkably long-lived.

The next two lines of Table 4 describe samples when censored observations are excluded. For instance, about one-third of the spells in the sample exist until the end of the reporting period (either because the product code is deleted or the sample period ends) so that the true length of the trade relationship is unknown. In the "observed stops" sample, these spells (that do not experience a failure during the sample period) are dropped to correct for right-censoring. This procedure implies that, by definition, spells of maximum length are excluded, thereby lowering observed trade duration. With this modification, the average length of a trade relationship in German imports is less than 2 years, with a median duration of just 1 year. Basically identical results are obtained when I additionally drop all lefttruncated spells for which the start date is effectively unknown ("observed startsstops").

Other sub-samples show the expected results. For instance, to deal with possible measurement errors in the statistics (where a trade relationship may be temporarily interrupted or end due to misreporting), I have considered, for each product-country pair, only the first reported spell in my sample ("first spell"), and I have also examined separately product-country pairs without multiple spells ("one spell only"). While the average trade duration in these sub-samples slightly increases to about 4 years, the majority of the examined spells lasts just 2 years, similar to the 
full sample. Finally, part of the explanation for the short duration of trade appears to be the small value of many trade transactions. Therefore, I have dropped spells with initial trade values below various threshold levels, and I also considered trade at more aggregate levels of industry classification. As expected, trade duration increases with trade value. However, sample size decreases rapidly for these modifications. More importantly, the finding of relatively short-lived trade relations remains unchanged, except perhaps for very large trade flows.

For the empirical analysis, I supplement the import values data with two other sorts of data. First, I obtain some additional trade information from Eurostat. For instance, Eurostat also reports, at the product-country level, import quantities (which allows computing import unit values) as well as the (corresponding bilateral) value of German exports (allowing to identify the extent of two-way trade in a similar product, i.e., "intra-product" trade).

Second, I match this product-level trade data set with other product features which I borrow from the recent trade literature. Rauch (1999), for instance, groups products into three categories (homogeneous products that are traded at organized exchanges, products that have a reference price, and differentiated products) and shows that patterns of international trade differ across these product groups. Broda and Weinstein (2006) provide product-level estimates of elasticities of substitution between varieties of foreign imports. Finally, Nunn (2007) identifies the degree to which the production of goods requires advanced intermediate inputs. Since the production of customized inputs may require more relationship-specific investment, Nunn (2007) argues that trade patterns are affected by a country's institutional (that is, contract enforcement) environment. In the following, I examine whether these product characteristics help explain the observed differences in the duration of trade.

\section{Results}

To explore the large amount of heterogeneity in the stability of German import patterns, I apply a set of statistical methods that were particularly developed for analyzing survival data. ${ }^{11}$ I perform the duration analysis in two steps. In a first step, I use a simple graphical approach to examine differences in exit rates across product-country pairs. Specifically, I estimate survival functions for trade relationships, divided along various lines, using the Kaplan-Meier product limit estimator. To categorize product-country pairs, I use three extensive sets of variables: country (i.e., supplier)-specific characteristics, product-specific variables, and measures capturing features specific to the German import market of a given product; the effect of these variables on survival rates is analyzed in univariate fashion. In a second step, I examine the interplay of potential factors affecting trade duration, estimating a stratified Cox proportional hazard model.

I begin with a discussion of possible country-specific determinants of trade duration. In choosing variables that might affect the duration of trade, it seems

\footnotetext{
11 In Nitsch (2007), I present accompanying results derived from various other estimation techniques.
} 
reasonable to explore, as a starting point, the standard determinants of bilateral trade volumes as typically used in the gravity model. Gravity variables are highly successful in explaining patterns of trade; they may also be relevant for the duration of trade. In addition, I have compiled a variable that captures the number of products Germany has imported from a particular country; this variable may proxy for trust or any other unobserved linkages that potentially affect bilateral transaction costs (with a broader range of products shipped possibly indicating a preferred supplier of Germany). ${ }^{12}$ Finally, I group spells by the yearly difference in the log of the nominal exchange rate which is used as a measure of exchange rate stability. When exchange rate changes have the potential to terminate a trade relationship, switching of suppliers might be an explanation for the low observed exchange-rate pass-through on domestic prices; see Campa and Goldberg (2005).

Figure 5 presents a series of graphs where Kaplan-Meier curves are plotted for the supplier-specific variables. Each line represents the survival function for a group of product-country pairs that exhibits a particular characteristic. In the top-left graph, for instance, pairs are grouped by the economic size of the exporting country (as measured by the country's GDP). The graph shows that country size clearly affects duration; exit rates are significantly higher for imports from (economically) smaller countries. ${ }^{13}$ Similar encouraging results are obtained for all other standard gravity variables. Unconditional survival probabilities are higher for import trade relationships with countries that have a high per capita income, are geographically close to Germany, and share similar institutions (such as language or membership in the European Union). Exchange rate movements, in contrast, have no measurable linear effect on exit rates; exit rates appear to be low for particularly stable exchange rates.

Figure 6 presents analogous graphs for various product-specific and relationshipspecific characteristics. I begin with two variables that may help describe a bilateral trade relationship apart from features of the product-supplying country: the (log) initial transaction value and the (log) bilateral unit value. Overall, the results strongly confirm intuition. Exit rates differ significantly by transaction size, with spells of larger initial trade value exhibiting higher probabilities of survival; that is, major bilateral trade linkages often remain in existence for longer periods of time. Also, exit rates turn out to be higher for products with large (log) unit values, possibly reflecting the low frequency of purchases of big-ticket items.

Results are much less convincing for product-related features, such as the (product-specific) elasticity of substitution. ${ }^{14}$ Based on univariate estimates of survival, there is no evidence that product varieties which may be easily replaced by others are imported over relatively shorter periods of time. I also explore two other product-specific variables, with mixed results. Similar to Besedeš and Prusa's

\footnotetext{
${ }^{12}$ In view of a possible positive correlation between trade volume and trade diversity, this variable may be of particular interest in the regression analysis.

13 The $95 \%$ confidence interval of the estimate is (in all cases) extremely tight and therefore not shown.

14 The elasticities are taken from Broda and Weinstein (2006) and graciously made available online by Christian Broda at http://faculty.chicagogsb.edu/christian.broda/website/research/unrestricted/ TradeElasticities/TradeElasticities.html. I use concordance tables from Eurostat to match SITC Rev.3 5-digit codes to $\mathrm{CN}-8$ codes.
} 
Country characteristics I
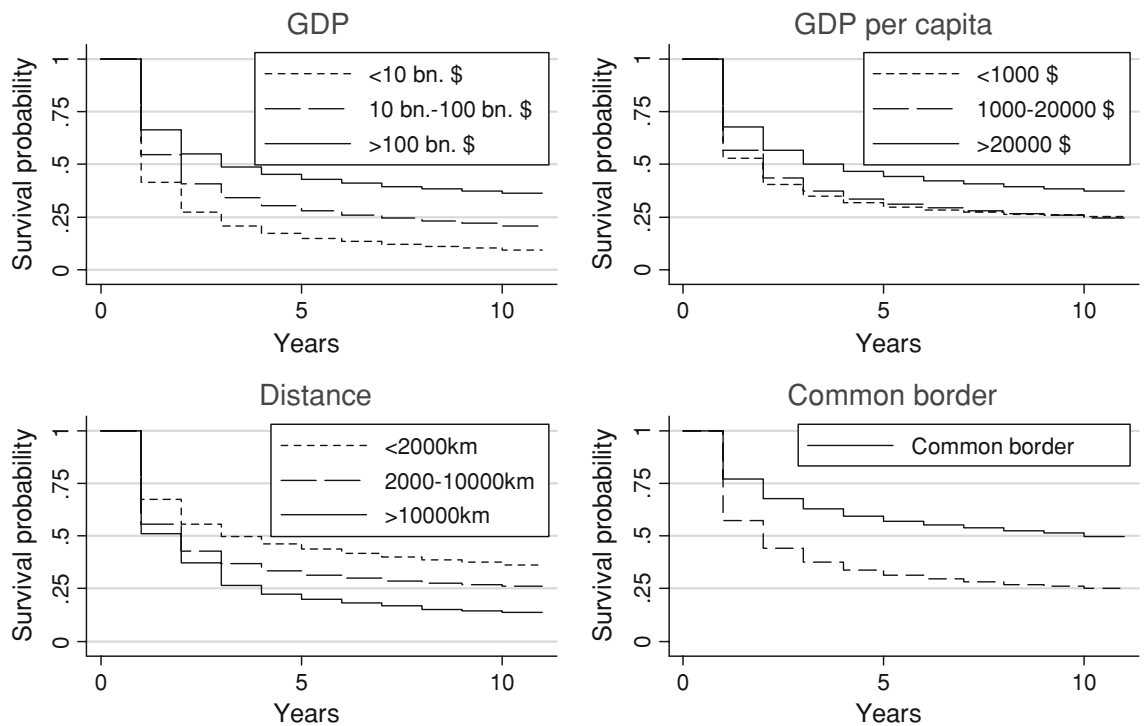

Country characteristics II
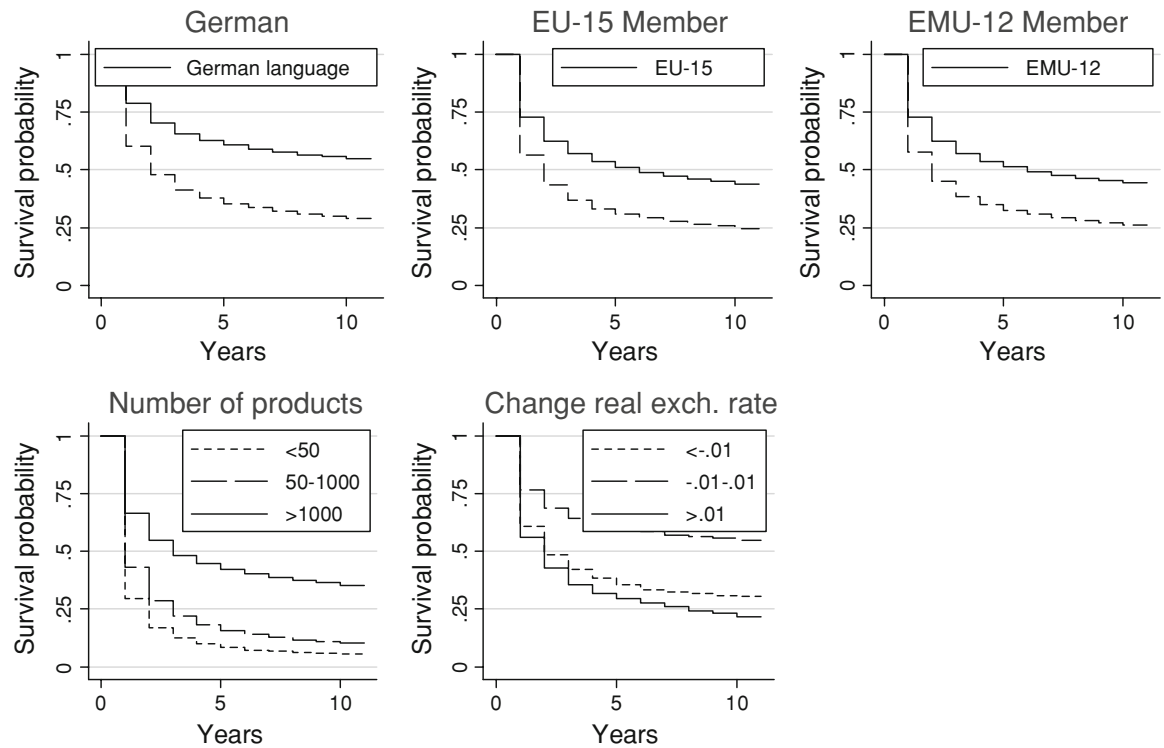

Fig. 5 Survival functions for country characteristics

(2006b) findings for the United States, trade in differentiated products, as defined by Rauch's (1999) classification, turns out to be relatively durable. Since differentiated products are characterized by non-standardized features, these products may require closer, more long-living trade relationships. Weaker results, in contrast, are obtained 


\section{Product characteristics}
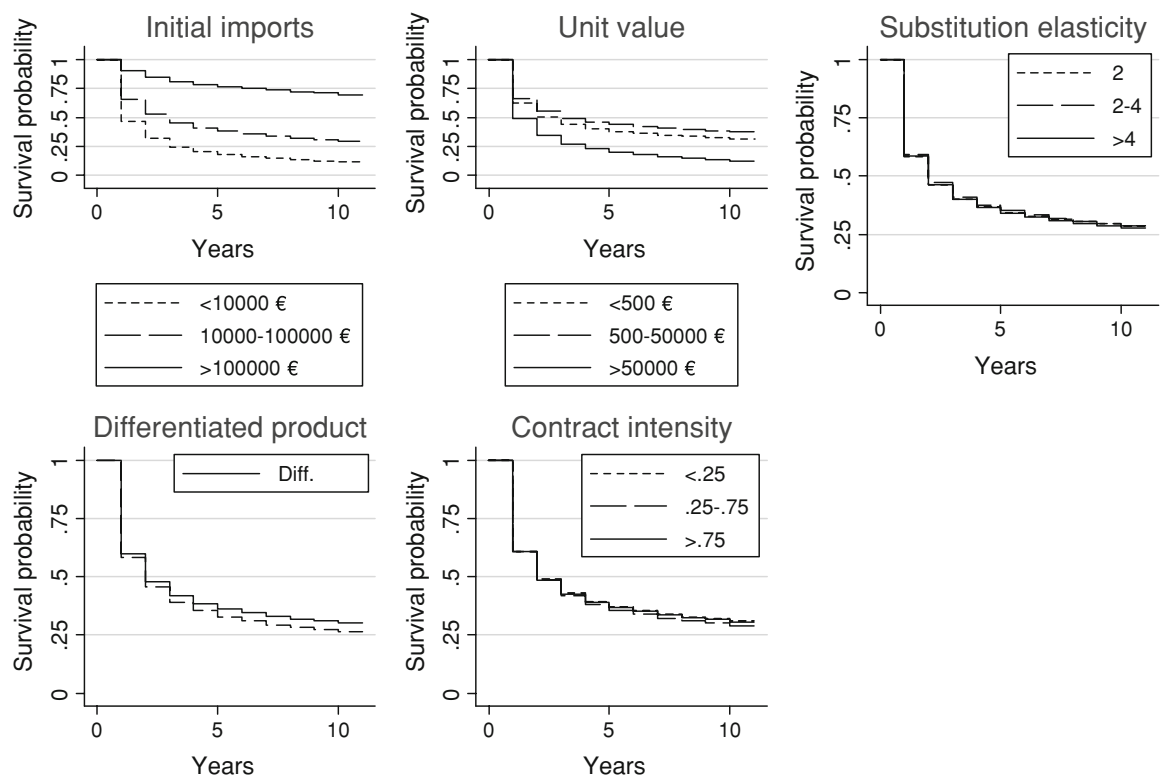

Fig. 6 Survival functions for product characteristics

for contract intensity, a measure of product sophistication that has been recently proposed by Nunn (2007). ${ }^{15}$

In Figure 7, I provide graphs for a third set of variables; these variables aim to describe the structure of the German import market. For instance, market size may matter for survival, with a larger market perhaps allowing exporters to accommodate temporary fluctuations in demand more easily. In practice, I use two measures of market size and find for both of these measures that market size lowers exit rates. Trade relations are more durable when the German import market is relatively large. Similarly, market share as measured by the fraction of bilateral trade in total German imports of a given product is strongly and positively associated with survival; major suppliers tend to serve the German market over longer periods of time. Another market characteristic is the number of countries supplying a particular product to Germany. Interestingly, the estimated probability of survival increases with the number of competitors; a possible explanation for this finding is that the number of supplying countries may be just another reflection of import market size. Finally, I make use of German export data. The value of German exports of a particular product to a country turns out to affect corresponding imports positively; two-way trade lengthens trade, especially above some threshold value of exports, perhaps because of greater trust or reciprocity in trade policies.

\footnotetext{
$\overline{15}$ Contract intensity measures the proportion of intermediate inputs that require relationship-specific investments in the production process.
} 

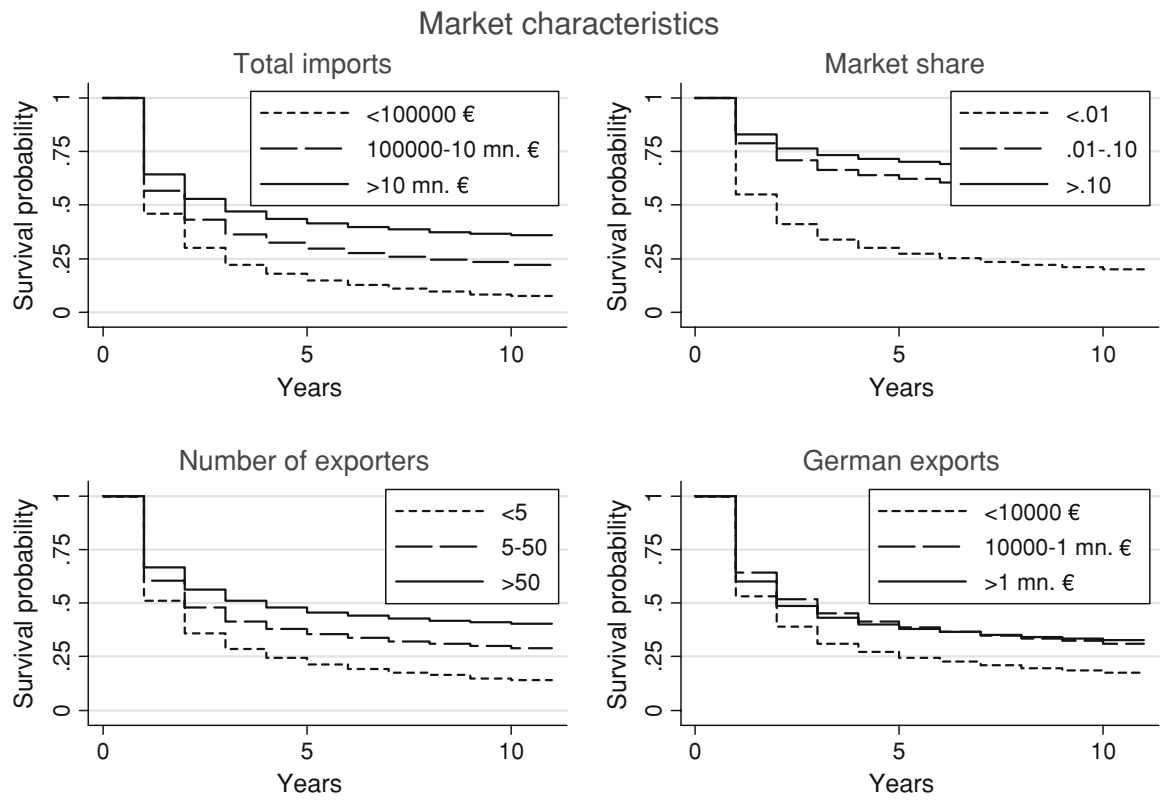

Fig. 7 Survival functions for market characteristics

In sum, this exploratory exercise suggests that the probability of survival in the German import market (and, thus, the length of trade relationships) differs along various lines. However, since the definition of bins for continuous variables is rather arbitrary, I do not intend to interpret the results too literally. Consequently, I use Cox proportional hazard regression to examine the effect of potential factors on trade duration.

Following Besedeš (2008), I estimate a stratified proportional hazards model. In the (standard) Cox model, the hazard function $h$ is parameterized as:

$$
h(t, x, \beta)=h_{0}(t) e^{x \beta},
$$

where $t$ denotes survival time, $x$ is a set of explanatory variables, and $\beta$ is a vector of coefficients to be estimated. In this model, there is a common unspecified baseline hazard function, $h_{0}(t)$, which characterizes how the hazard function changes as a function of survival time, while the function $e^{x \beta}$ characterizes how the hazard function changes as a function of subject covariates. In the stratified version of this model, I allow the baseline hazard function to vary; that is, the baseline hazard function becomes stratum-specific. In the actual implementation, I use (World Bank) regions and 1-digit industries as stratification variables.

The results are reported in Table 5. The first column reports estimation results when the full set of covariates is included. This model comes at the cost of small sample size since for some variables only a limited number of observations are available. Reviewing the results, most of the findings from the survival analysis are confirmed. For instance, the estimation results from the hazard rate model are strongly supportive for the gravity-based determinants of durability in trade. Similar 


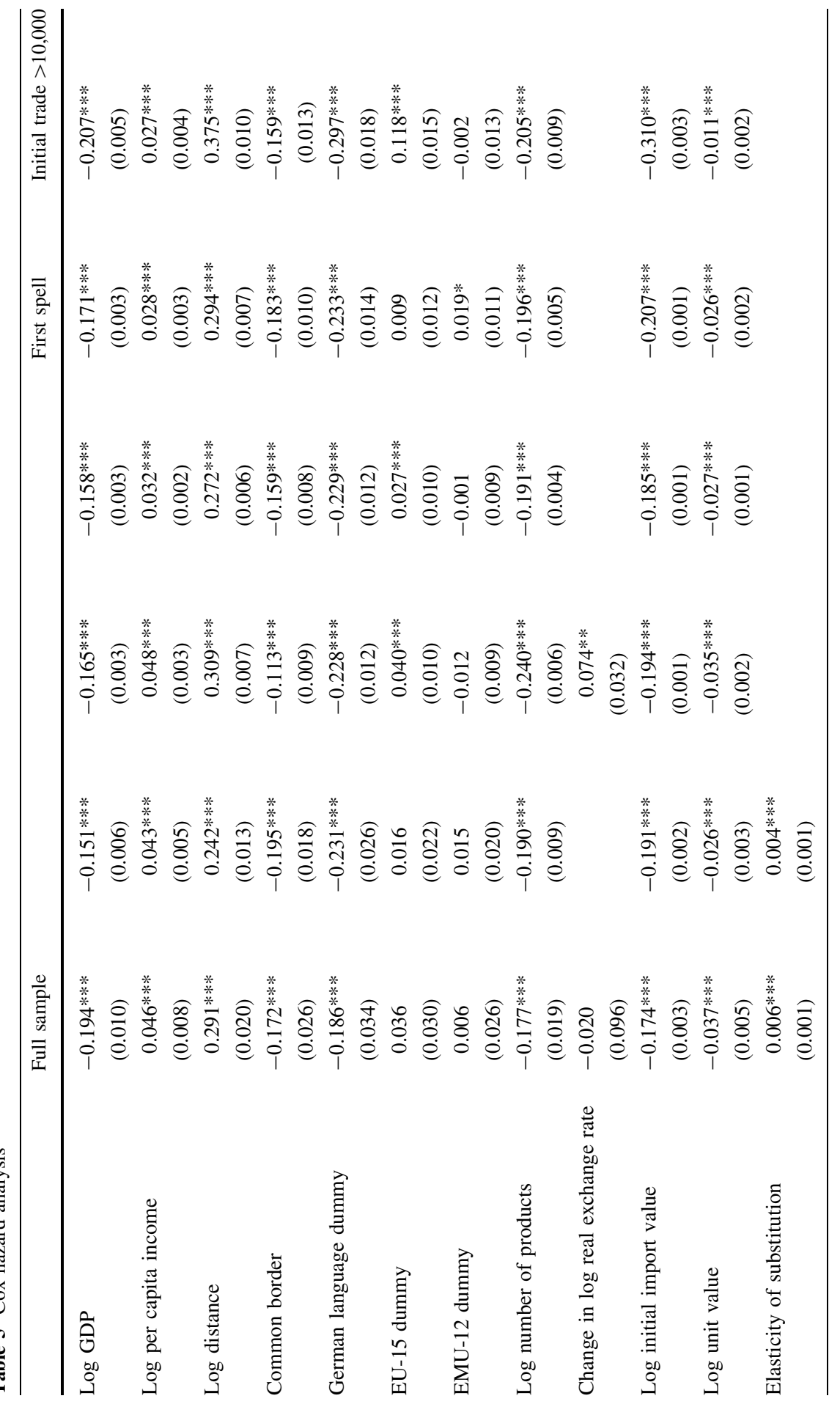




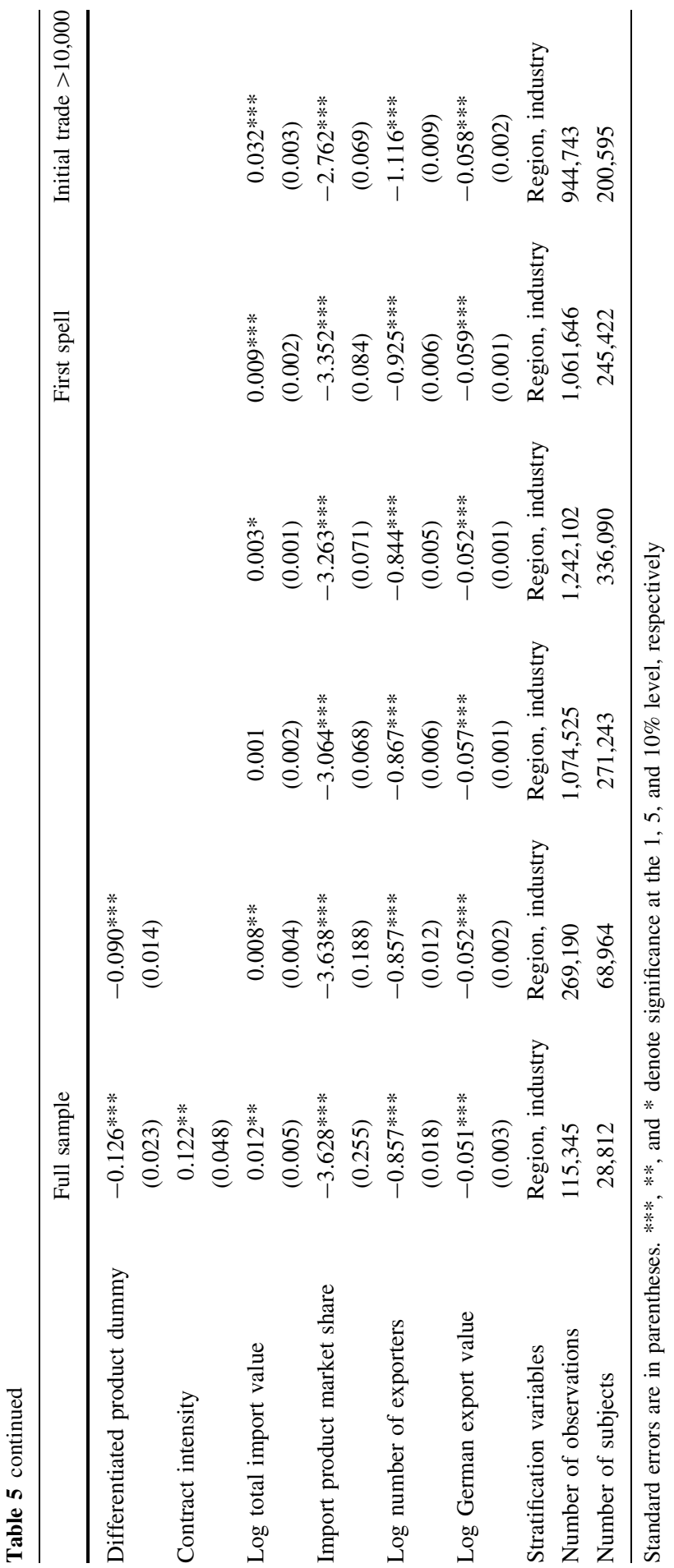


to Kaplan-Meier estimates, the key gravity variables do not only affect the magnitude of trade but also matter for trade duration: larger economic size is associated with lower hazard rates and thus longer spells, while trade with more distant partners is on average more short-lived. In addition to size and distance, also the estimated coefficients on per capita income, common border and common language are statistically highly significant. Interestingly, the results suggest that, after controlling for GDP, imports from richer countries have higher hazards, perhaps because of greater substitutability among suppliers or more narrowly defined product groups. A common land border with Germany and a common language lengthen trade spells, while membership in the European Union (EU-15) and EMU membership (EMU-12) have no effect on hazard rates. Of the two remaining country-specific regressors (other than standard gravity variables), product diversity turns out to be relevant: there is a strong and significant negative association between hazard rates and the number of imported products. The coefficient on the exchange rate variable, in contrast, is statistically indistinguishable from zero.

Reassuringly, also for other characteristics of bilateral trade relationships, the key findings from the survival analysis turn out to be reasonably robust. In particular, the coefficient estimates derived from the hazard model are not only (qualitatively) quite similar to those of Figs. 5, 6, 7, but the results are for some variables even stronger. For instance, estimated hazard rates are lower for major bilateral trade pairs (as proxied by initial trade value and market share) and for trade in products with low unit values, thereby confirming previous findings. In addition, however, there is also clear evidence that products that exhibit a lower elasticity of substitution as well as differentiated products are characterized by lower hazards. As before, suppliers face lower hazards when there are more competitors and there is two-way trade.

As noted above, missing observations for a few variables seriously limit the size of the sample. Therefore, to increase sample size, I sequentially drop these variables. The results are tabulated in columns 2-4 of Table 5. Despite dramatic increases in sample size, the key results remain basically unchanged. The most notable difference is the positive coefficient on the exchange rate variable; contrary to expectations, the estimated coefficient suggests that a foreign depreciation (i.e., an increase in the foreign country's real exchange rate) is associated with higher hazard rates, a result that is possibly due to non-linearities in the effect of exchange rate volatility on survival (as suggested by the Kaplan-Meier estimates).

I have also examined different samples. Column 5 presents coefficient estimates derived from a sample of first spells only (thereby excluding episodes of multiple spells which may be the result of statistical errors); column 6 reports results for particularly large trade flows with initial transactions above a threshold of 10,000 euro. Again, these perturbations have little effect on the results. For both samples, I find estimates similar to the default regression.

In sum, it turns out that the estimation results are remarkably robust across different samples and specifications. ${ }^{16}$

\footnotetext{
16 This finding also includes all the other sub-samples described in Table 4 for which results are unreported to economize on space.
} 


\section{Conclusion}

International trade patterns at the product level are surprisingly dynamic. Products are typically obtained from various international sources; many trade transactions are small in value. Accordingly, the majority of bilateral trade relationships exist for just a few, often only one to three, years.

In this paper, I examine empirically the duration in German import trade at the 8digit product level from 1995 to 2005. Not surprisingly, there are large differences in the duration of trade: while many trade transactions are short-lived, a sizable fraction of bilateral trade pairs also appears to survive for more than a decade. Given these discrepancies, I explore a wide range of potential determinants of trade duration, thereby extending previous work by Besedeš and Prusa (2006b) and Besedeš (2008). Using various techniques, I find that survival probabilities are indeed affected by exporter characteristics, product type features and market structure. In particular, I show that the standard "gravity" determinants of trade do not only affect trade values but also trade duration. In addition, the duration of exporting a product to Germany is longer for trade relationships with a large initial transaction size and for products with a low elasticity of substitution. Finally, trade pairs that command a large share of the German import market and trade pairs characterized by two-way trade have on average lower exit rates.

Acknowledgments Volker Nitsch thanks an anonymous referee and seminar participants at the University of Amsterdam, Free University Berlin, Social Science Research Center Berlin (WZB), CESifo Munich, Darmstadt University of Technology, University of Duisburg, the London School of Economics, the 2007 DEGIT conference, and the 2007 meetings of the CEA, EEA, ETSG, Midwest Trade and VfS for helpful comments.

\section{References}

Baldwin, R., \& Harrigan J. (2007). Zeros, quality and space: Trade theory and trade evidence. NBER Working Paper 13,214. Cambridge, MA: National Bureau of Economic Research.

Baldwin, R., \& Krugman, P. (1989). Persistent trade effects of large exchange rate shocks. Quarterly Journal of Economics, 104(4), 635-654.

Besedeš, T. (2008). A search cost perspective on duration of trade. Review of International Economics, 16(5), 835-849.

Besedeš, T., \& Prusa, T. J. (2006a). Ins, outs, and the duration of trade. Canadian Journal of Economics, 39(1), 266-295.

Besedeš, T., \& Prusa, T. J. (2006b). Product differentiation and duration of US import trade. Journal of International Economics, 70(2), 339-358.

Broda, C., \& Weinstein, D. E. (2006). Globalization and the gains from variety. Quarterly Journal of Economics, 121(2), 541-585.

Campa, J. M., \& Goldberg, L. S. (2005). Exchange rate pass-through into import prices. Review of Economics and Statistics, 87(4), 679-690.

Egan, M. L., \& Mody, A. (1992). Buyer-seller links in export development. World Development, 20(3), 321-334.

Evenett, S. J., \& Venables, A. J. (2002). Export growth in developing countries: Market entry and bilateral trade flows. London: World Trade Institute and London School of Economics.

Feenstra, R. C., \& Rose, A. K. (2000). Putting things in order: Trade dynamics and product cycles. Review of Economics and Statistics, 82(3), 369-382.

Gopinath, G., \& Rigobon, R. (2008). Sticky borders. Quarterly Journal of Economics, 123, 531-575. 
Grossman, G., \& Helpman, E. (1991). Innovation and growth in the global economy. Cambridge, MA: MIT Press.

Haveman, J., \& Hummels, D. (2004). Alternative hypotheses and the volume of trade: The gravity equation and the extent of specialization. Canadian Journal of Economics, 37(1), 199-218.

Helpman, E., Melitz, M., \& Rubinstein, Y. (2008). Estimating trade flows: Trading partners and trading volumes. Quarterly Journal of Economics, 123(2), 441-487.

Kehoe, T. J., \& Ruhl, K. J. (2003). How important is the new goods margin in international trade? Federal Reserve Bank of Minneapolis Staff Report 324. Minneapolis: Federal Reserve Bank of Minneapolis.

Kiefer, N. M. (1988). Economic duration data and hazard functions. Journal of Economic Literature, 26(2), 646-679.

Nitsch, V. (2007) Die another day: Duration in german import trade. CESifo Working Paper 2085. Munich: CESifo.

Nunn, N. (2007). Relationship-specificity, incomplete contracts and the pattern of trade. Quarterly Journal of Economics, 122(2), 569-600.

Rauch, J. E. (1999). Networks versus markets in international trade. Journal of International Economics, 48(1), 7-35.

Rauch, J. E. (2001). Business and social networks in international trade. Journal of Economic Literature, 39(4), 1177-1203.

Redding, S. (2002). Specialization dynamics. Journal of International Economics, 58(2), 299-334.

Vernon, R. (1966). International investment and international trade in the product cycle. Quarterly Journal of Economics, 80(2), 190-207. 